\title{
Article
}

\section{Looking for Ways to Increase Student Motivation: Internationalisation and Value Innovation}

Kuznetsov, Andrei and Kuznetsova, Olga

Available at http://clok.uclan.ac.uk/5038/

Kuznetsov, Andrei ORCID: 0000-0003-4539-0711 and Kuznetsova, Olga (2011) Looking for Ways to Increase Student Motivation: Internationalisation and Value Innovation. Higher Education Quarterly, 65 (4). pp. 353-367. ISSN 09515224

It is advisable to refer to the publisher's version if you intend to cite from the work. http://dx.doi.org/10.1111/j.1468-2273.2011.00493.x

For more information about UCLan's research in this area go to http://www.uclan.ac.uk/researchgroups/ and search for < name of research Group>.

For information about Research generally at UCLan please go to http://www.uclan.ac.uk/research/

All outputs in CLoK are protected by Intellectual Property Rights law, including Copyright law. Copyright, IPR and Moral Rights for the works on this site are retained by the individual authors and/or other copyright owners. Terms and conditions for use of this material are defined in the policies page.

\section{CLoK}

Central Lancashire online Knowledge www.clok.uclan.ac.uk

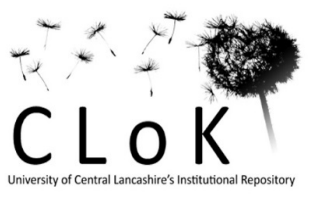


Higher Education Quarterly, 0951-5224

DOI: $10.1111 / j .1468-2273.2011 .00493 . x$

Volume 65, No. 4, October 2011, pp 353-367

\title{
Looking for Ways to Increase Student Motivation: Internationalisation and Value Innovation
}

\author{
Andrei Kuznetsov, Lancashire Business School, \\ akuznetsov@uclan.ac.uk \\ and Olga Kuznetsova, Manchester Metropolitan University, \\ o.kuznetsova@mmu.ac.uk
}

\begin{abstract}
Understanding what constitutes the perceived value of foreign education to international business students is critical for business schools in order to achieve their recruitment targets. One established method relies on a financial interpretation of the costs and benefits of business education. By contrast, this study advocates a holistic approach by employing the concept of "internal" and "external" career success as its theoretical underpinning. A survey of undergraduate Chinese students in two British business schools based on such approach provides confirmation of the importance of an individual's judgement of own success as the foundation of value-related expectations and suggests that academic practice should be concerned with a wider range of competencies and responses to individual attitudes, shifting emphasis towards a greater spectrum of social values.
\end{abstract}

\section{Introduction}

The institutions of higher education in many countries, of which the United Kingdom is a prime example, are no longer immune to concerns about market share, productivity, return on investment and customer satisfaction (Olssen and Peters, 2005; Marginson, 2006; Molesworth et al., 2009). Following the commodification of tertiary education, the higher education sector increasingly acquires features characteristic of a service market (Jongbloed, 2003; Newman and Jahdi, 2009). This situation makes it admissible and even necessary to employ some of the tools developed by marketing and management scholars for the analysis of the relations between universities and students (Hemsley-Brown and 
Oplatka, 2006). The purpose of this paper is to highlight the role and dynamics of 'value creation' in the educational market, using UK business schools as an example. It has as its focus international students, whose importance for British universities in general and business schools in particular has increased dramatically over the recent years.

Determining the value of business education as perceived by students is not a new question for educational literature. One established method is to look at career success as a sequence of promotions and associated salary increases triggered by a successful completion of a business degree (Tracy and Waldfogel, 1997). Recently, however, there has been growing concern that the financial criteria alone are not sufficient to give a full representation of success. Educationalists are urged to pursue a holistic approach and explore 'perceptions rather than numbers, and aspects other than financial' (Carmichael and Sutherland, 2005) in order to reveal the true value of education as seen by potential students and, as a consequence, to help universities to strengthen their competitive position by making sure that they provide maximum response to the expectations of their potential students. However, as far as business schools are concerned, research is focused on the exploration of the attitudes of postgraduate students, mostly on MBA courses (Caruana and Spurling, 2006). With a view to contributing to a discussion on how British business schools serving the international undergraduate market should shape their value proposition, this study has undertaken to investigate the outlook of international undergraduate business students.

The paper begins by introducing the notions of customer value and value innovation and their relevance to the university sector. To achieve a holistic rather than one-dimensional 'financial' approach to value creation it applies the concept of 'internal' and 'external' careers and career success as a theoretical underpinning for determining the constituents of the value of education perceived by students. It proceeds to test the validity of the holistic versus financial view on the value of education using as a tool a survey of Chinese students in two British business schools. The concluding sections of the paper summarise the findings, discuss their implications and make suggestions for future research.

\section{Internationalisation and customer value innovation}

An increasing proportion of undergraduate and of postgraduate students is recruited abroad. The number of foreign students in the OECD countries has doubled from 2000-2007 to 2.5 million, which represents 84 per cent of world's foreign students (Systèm d'Observation Permanente sur la Migrations (SOPEMI), 2010). Almost half a million 
international students study at UK universities. Of all programmes on offer, business and administrative studies have proved to be the most popular: in 2008-2009 they attracted the largest number of foreign students, as much as the next three most popular subjects taken together (UK Higher Education International Unit, 2010). Business education was particularly popular with non-EU nationals with Chinese being in the majority.

As a consequence of the mobility of the student population, higher education institutions in one country are effectively in direct competition with similar institutions anywhere in the world. This is particularly true of business schools: there are approximately 2,700 programmes that use English as the primary language of instruction delivered at more than 350 institutions in 35 countries (Wilson, 2007, p. 84). Globalisation has made necessary the restructuring of higher education and educational practices (in particular in business schools because of their student cohort that has a reputation for demanding value for money) leading to the commodification of education (Sappey and Bamber, 2007; Healey, 2008). As a result the task of sustaining engagement with international students as customers acquires great importance (Currie and Newson, 1998; Sappey and Bamber, 2007).

There is a conflict of opinions in the literature regarding the appropriateness of viewing university students as customers (Armstrong, 2003; Kamvounias and Varnham, 2006; Finney and Finney, 2010). There is no doubt that following functional difference between profitseeking organisations and universities the student-as-customer paradigm has serious limitations in its application. However, this paper shares the position of those authors who, like Brennan and Bennington (2000), argue that this paradigm has a useful purpose as long as the term 'customer' is applied in a wider sense as anyone who uses or experiences the services of another. It allows obversation and analysis of teaching and learning as a market product and an object of strategic management. One aspect of this approach is that it urges higher education institutions to focus on perfecting a 'customer value proposition' (Porter, 2007) because of its importance as a competitive tool. A customer value proposition consists of the sum total of benefits that a vendor promises that a customer will receive in return for the customer's associated payment. As Porter (2007) puts it, for an organisation, the customer value proposition is about recognising where, how, when, for whom and in which form it can create 'value innovation' for customers to achieve success in the market place. The term, first used by Lanning (1998), emphasises the extended interpretation of value as the customer's total experience with 
a product (service), which contrasts to the narrowly defined 'economic value' linked to price alone. Accordingly, for an organisation developing a value proposition this implies defining such a total experience as much as delivering it to the customer. Research has revealed a significant difference between the levels of satisfaction reported by home and overseas business students (Mai, 2005) suggesting that foreign students may have not necessarily higher but different expectations. This highlights two challenges traditionally identified with commercial concerns that now face higher education institutions determining value offerings that (a) constitute real value for customers and (b) need to be introduced or increased to meet customer needs. The strategy addressing these issues is known as value innovation. The empirical study that follows, by focusing on the perceptions of value held by foreign students, provides evidence that can be used by British business schools to optimise the value innovation process and reinforce their position in the international market.

Customer value can be defined as 'the customers' perception of what they want to have happen in a specific use situation, with the help of the service or product offering, in order to accomplish a desired purpose or goal' (Woodruff and Gardial, 1996, p. 54). The article infers that for business students the perceived value of education abroad is linked to the value added that foreign education offers, which, when compared with home education, leads to the development of the graduate's competitive advantage (Baruch et al., 2005; Carmichael and Sutherland, 2005). Consequently, business schools cannot be effective in their mission of meeting the demand for quality education if they are not fully aware of what may possibly represent such perceived value added; what foreign students expect and what are the demands of the global market place.

Research has established that for business students the prime motivation for an overseas education is career development expectations (Devos, 2003; Isserstedt and Schnitzer, 2005). Summarising existing research Middlehurst and Woodfield (2007, p. 56) concluded that study abroad is 'as much about gaining a cultural experience and enhanced career prospects as about academic study for its own sake'.

Students are aware that professional competence is not the only asset that employers associate with a foreign university degree: they go abroad motivated by the desire to acquire complementary skills resulting in enhanced capabilities and adaptability that increasingly become important features of a successful career (Teichler, 2004). Independent of the amount of extra knowledge gained at a foreign university, the fact that the individual has studied abroad is often sufficient for employers as a 
proof of a strong personality, perseverance and substantial social skills (Murray and Robinson, 2001). Many recognise that the acquisition of intercultural competence and the skill of adjustability to change increasingly becomes a necessity for the modern labour force (Stier, 2003; Isserstedt and Schnitzer, 2005). This finding has serious implications. It suggests that study abroad, because of the employers' attitude, becomes an increasingly appealing option for students who previously were reluctant to do so for the reason that they saw little use for the knowledge acquired in a foreign country during their later professional life.

This and similar evidence makes it apparent that exposure to educational and social experience in a foreign environment may be as important a potential career advantage as a formal degree from a foreign university and therefore constitutes customer value in its own right. This is bound to have consequences for business schools as and when they pursue value innovation in search of a competitive advantage. Hosting institutions can no more be satisfied with simply playing the role of knowledge providers and skills developers; they are expected to offer learning experience that overreaches conventional academic boundaries. In the modern context the creation of value within the university sector goes beyond the process of merely transmitting the knowledge: the existential component becomes as important. Consequently, understanding the reasons why students want to study abroad is not sufficient. Equally significant is the understanding of what students expect to gain from their time overseas. As far as business students are concerned this involves discovering the priorities of their long-term career agenda.

\section{Career success as a measure of customer value}

Recent literature provides clear evidence that for a modern business person exposure through learning to a particular social experience becomes as important as obtaining formal knowledge. This suggests that in a customer-driven market the providers of education services are increasingly required to accommodate the expectations of customers who wish to experience an exposure to a different educational and cultural system. It is appropriate, therefore, to question the measure to which the traditional approach towards evaluating the benefits of business education based on comparing the financial costs and gains of investment into tertiary education (analysis of this approach can be found in Baruch and Peiperl, 2000; Connolly, 2003; Pfeffer and Fong, 2003; Schoenfeld, 2007) can account for the existential aspect of acquiring a university degree. 
There is a stream of literature that maintains that career success in personal terms may not necessarily equal public success. This approach advocates a distinction between 'external' and 'internal' careers and, accordingly, the external and internal measures of career success (Hay and Hodgkinson, 2006). The internal career is defined as a person's own subjective idea about work and life, and his or her role within it (Schein \& Van Maanen, 1977). Internal career success thus refers to an individuals' judgement of their own success (Gattiker and Larwood, 1986) and self-fulfilment, challenge and satisfaction are frequently used to define it psychologically (Weick and Berlinger, 1989). The external career, on the contrary, is judged almost exclusively on the basis of progression in hierarchical positions and salary increases. It is conventionally known as 'fast track' career advancement. Scholarly evidence of comparative levels of internal and external career success of individuals is unfortunately missing in career development research, so it is difficult to say how often they occur simultaneously (Mintzberg, 2004). It is argued though that an internal career progression is not inferior to an external progression and might be as satisfying.

Accordingly, in respect of value creation it is important that universities recognise a distinction between the explicit elements of value added related to the anticipated financial remuneration, following the completion of a university programme, and the 'inner-value' elements that need not necessarily hold a monetary representation. Carmichael and Sutherland (2005) identified the following three 'inner-value' components as the most important: (a) increased confidence; (b) broader worldview, insight and wisdom; (c) significantly greater knowledge. Carmichael and Sutherland (2005, p. 67) further point out that, 'learning facilitators should view students as key stakeholders of the business, with both obligations and expectations of the relationship. They should be aware of and empathetic to the cost and benefit variables that are important to students, and support them to experience the holistic range of benefits that they may enjoy'. Academic staff therefore, can enhance the effectiveness of learning interventions by using methodologies that go beyond traditional subject-related knowledge transfer.

\section{Value added of foreign education: the study}

This enquiry investigates whether or not the perceptions of educational value held by international undergraduate students are influenced by the inner-value perspectives. A common approach to measuring student attitudes in educational literature is to employ a survey technique (Gibson, 2010). Because the current examination is concerned with 
perceptions of international students at the stage when they were making their choices about where and what to study, the sample needed to be of relatively new students, who would be able to recall their experiences more fully. Appleton-Knapp and Krentler (2006) have demonstrated that expectations at the beginning of the course are often different from the recollection of expectations at the end of the experience and that the valence and intensity of the experience affects the reconstruction of earlier expectations. Accordingly, students who had just started their studies were surveyed. The sample includes undergraduate Chinese students starting a course of study at two British business schools. Students from China made a natural choice as a target group as they currently constitute the biggest population of foreign nationals studying in the UK (UCAS, 2009, p. 29). Empirical data were collected through questionnaires. This method was chosen as the most practical way to monitor the opinion of the relatively large group of people and also because in the literature on research methods surveys are described as a powerful tool for collecting data on human characteristics such as attitudes, thoughts and behaviour (Johnson and Duberley, 2000; EasterbySmith et al., 2002).

In developing the questionnaire a wide range of sources on the perceived value of foreign education has been consulted. This includes academic studies, anecdotal evidence, participant observations, international and national reports, including those on employers' expectations about the experience of recruits. The chosen variables were extracted by content analysis of the works of Useem and Karabel (1986), Baruch et al. (2005) and Carmichael and Sutherland (2005). They are described in Table 1. A self-administered questionnaire was tested in a pilot survey of a selected group of Chinese students to check that the questions were formulated in a way that created no comprehension difficulties for the respondents. Participation in the survey was a matter of free choice for the students. However, because researchers had access to a limited population of students an in-class survey was applied in an attempt to minimise non-response rate. Only seven students declined to participate. The main survey has produced 54 valid returns. The size of the sample of the survey is similar to other published research in this area (for example, Carmichael and Sutherland, (2005) used a sample of 58; Mihail and Elefterie (2006) of 68). All respondents but one were from mainland China; 55 per cent of respondents were female; the average age of respondents was 22.5 years.

Following Angelidis and Ibrahim (2004) a forced choice format was adopted as especially suitable for social research because of its ability to 


\section{TABLE 1}

Relative importance of human capital elements of international higher education value-added

\begin{tabular}{|c|c|c|c|c|c|c|}
\hline & Variables description & $\mathrm{N}$ & Min & Max & Mean & $\begin{array}{l}\text { Std. } \\
\text { deviation }\end{array}$ \\
\hline 1 & Self-development & 25 & 3.00 & 5.00 & 4.1600 & 0.68799 \\
\hline 2 & Increased confidence & 25 & 3.00 & 5.00 & 4.1200 & 0.72572 \\
\hline 3 & $\begin{array}{l}\text { Enhanced ability to understand } \\
\text { the world around you }\end{array}$ & 25 & 2.00 & 5.00 & 4.1200 & 0.88129 \\
\hline 4 & $\begin{array}{l}\text { Getting an insight into a new } \\
\text { culture }\end{array}$ & 25 & 3.00 & 5.00 & 3.9600 & 0.78951 \\
\hline 5 & $\begin{array}{l}\text { Increased ambition for achieving } \\
\text { career goals }\end{array}$ & 25 & 2.00 & 5.00 & 3.8000 & 0.95743 \\
\hline 6 & Control own destiny & 25 & 2.00 & 5.00 & 3.6800 & 0.94516 \\
\hline 7 & Improved self-esteem & 25 & 2.00 & 5.00 & 3.6800 & 0.94516 \\
\hline 8 & Getting new social skills & 25 & 2.00 & 5.00 & 3.6800 & 1.02956 \\
\hline 9 & $\begin{array}{l}\text { Getting a different perspective } \\
\text { on things }\end{array}$ & 25 & 2.00 & 5.00 & 3.6400 & 0.95219 \\
\hline 10 & Greater job satisfaction & 25 & 1.00 & 5.00 & 3.4800 & 1.12250 \\
\hline
\end{tabular}

limit a respondent's social desirability bias. Questions were designed to elicit information on students' perception of the expected value added of being educated abroad and the factors that determine this perception. As is often the case in literature measuring student satisfaction with emphasised mean scores, a 5-point Likert-like agreement scale (for example, 1 to $5=$ very unimportant to very important; strongly agree to strongly disagree) was used in all questions except one for which a 9-point scale was employed to allow respondents to express themselves with greater precision. To maintain anonymity of the respondents, they were not required to provide personal details.

The current study has unavoidable limitations that it shares with numerous other survey-based investigations. First, the use of nonprobability based quota sampling and the limited defined population meant that the sample is biased, so the findings should be taken with caution. Second, the results are based on self-reporting of the respondents. Despite the fact that this method is widely accepted in social sciences, further research will benefit from some form of triangulation that synthesises data from multiple sources. Third, the research looked at a group of students who all came from the same foreign country while available research suggests that perceptions may differ by country (Middlehurst and Woodfield, 2007). These limitations restrict the generalisability of results, which nonetheless have investigative value 
because they reveal perceptions held by a currently dominant group of foreign students and set up a point of reference for future comparative cross-country studies.

\section{Findings and discussion}

The outcomes of the survey broadly confirm the views expressed in the literature about the educational value-added of studying abroad. It first undertook to find out if the respondents would confirm the opinion that the prestige of a foreign degree is not the main stimulus to study abroad. The survey revealed that the respondents did not necessarily consider domestic education inferior: the answers to the question 'Do you think that obtaining your degree in the UK will give you more status than a similar degree received from a Chinese university?' has brought very close results: yes ( 55 per cent), no ( 45 per cent). The investigation proceeded to establish the relevance of what some authors call the 'internal measures of career success' (Gattiker and Larwood, 1986; Baruch et al., 2005, p. 52). The students were asked to express their preferences using a 9-point scale. On this scale, points 1 to 4 indicated the preference (from 'extremely important' to 'quite important') for the financial benefits of business education and points 6 to 9 denoted the preference (from 'quite important' to 'extremely important') for the non-financial benefits of business education. The choice of 5 signified that the respondent valued both types of benefits equally. The data (see Fig. 1) demonstrate that the majority of respondents put significant value on non-financial benefits of foreign education: 50 per cent chose the scale points of 6 and above while 32 per cent by choosing the scale point 5 indicated that they allocated equal importance to both sets of benefits. Only 20 per cent of respondents explicitly preferred financial benefits over non-financial benefits.

Further, the survey ranked different 'inner-value' elements according to the importance that international students attributed to them (see Table 1). 'Self development' came out on top with the mean of 4.16 (out of 5) and a fairly narrow dispersion of results $(\sigma=0.69)$, suggesting that this preference was robust across the whole sample population. Together with 'self development', 'increased confidence' and 'enhancing your ability to understand the world around you' completed the group of the three most favoured choices with the mean above 4 . The second group contained such variables as 'gaining an insight into a new culture' and 'increased ambition for achieving career goals' with the mean of, respectively, 3.96 and 3.80. The next group of priorities included 'control own destiny', 'improved self-esteem', 'getting new social skills' and 'getting a 


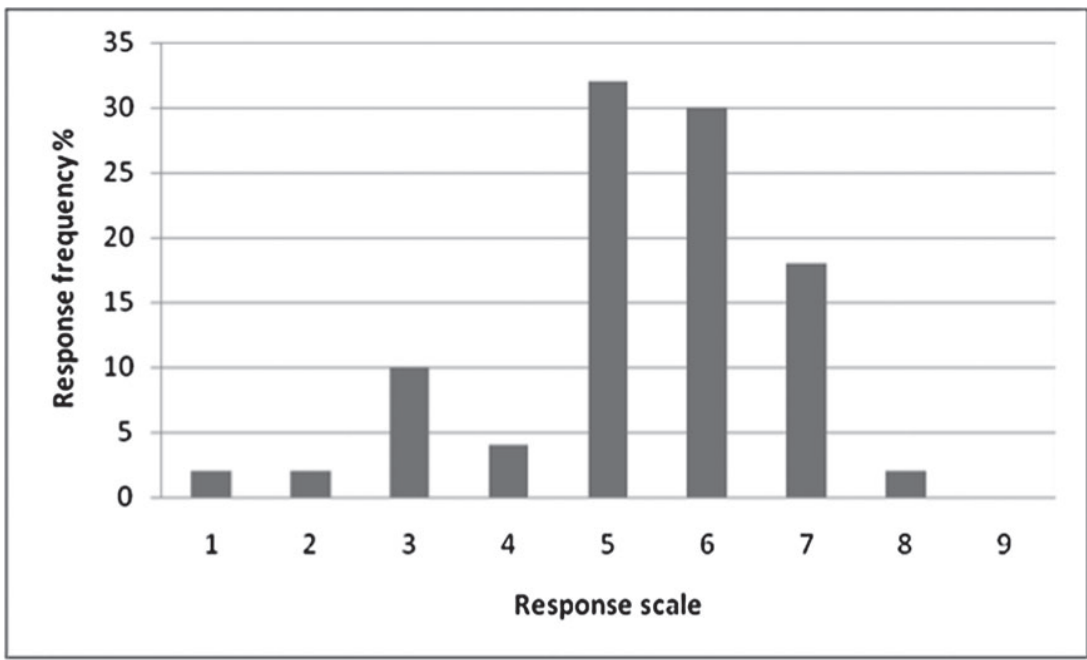

Figure 1 The spread of student preferences for the financial and non-financial benefits of education

Note: scale points 1 to 4 indicate preference for financial benefits of education, 6 to 9 indicate preference for non-financial benefits of education and 5 indicates that the respondents valued both types of benefits equally.

different perspective on things' with the means ranging from 3.68 to 3.64. Finally, 'greater job satisfaction' occupied the last place with the mean of 3.48. Importantly, the means for all variables are noticeably above the midpoint of the scale, indicating that all these parameters were perceived as important by the respondents.

This dispersion of preferences suggests that the sought outcomes of foreign education are far more comprehensive that those that can be measured in salary increases and visible career advancement. The 'internal career' clearly is an important consideration for international students. Internal career's success refers to an individual's judgement of their own achievements and is frequently defined psychologically and subjectively when assessing self-fulfilment, coping with professional challenge and job satisfaction. This entails that academic practice should be concerned with a wider range of competencies and responses to individual attitudes than is normally associated with the learning provisions.

It is true that the enhancement of student competency has always been the prime task of the universities. However, the modern context mandates that the creation of value within the university sector goes 
beyond the process of mere knowledge transfer. It begins to incorporate what Carmichael and Sutherland (2005) call meta-competencies. These fall broadly into the areas of communication, gathering and interpretation of data from a variety of sources, problem solving, systems thinking, ability to apply the use of technology in the workplace, working in groups, teams or communities, using mathematical concepts and managing oneself and one's own learning and development. The metacompetencies are 'essential skills that underpin success in education, employment, lifelong learning and personal development' (Carmichael and Sutherland, 2005, p. 58).

\section{Conclusions and recommendations for future research}

The internal career theory provided the starting ground for the hypothesis that the role of straightforward knowledge transfer has been diminishing; instead international students are increasingly looking for social skills and experience that will enrich them as individuals. This attitude seems to be a reaction to the realisation, first, that the very fact of possessing the experience of studying abroad may in itself be a competitive advantage in the labour market and, second, that the importance of self-fulfilment, challenge and satisfaction grow as inducements for choosing to study abroad. This empirical study provides confirmation of the importance of an individual's judgement of his or her own success. This suggests that academic practice should be concerned with a wider range of competencies and responses to individual attitudes, shifting emphasis towards a greater spectrum of social values.

Cross-cultural diversity of students presents academics with the challenge of effectively managing this diversity and using it to the benefit of the teaching process. A possible solution is to examine international students' self-knowledge in order to learn from the students themselves more about the expectations and demands of overseas students. In this context it is particularly important not to lose sight of the notion commonly acknowledged in literature that teaching is not just a product of training but first and foremost a personal interaction between individuals. Accordingly, the ability of the tutor to be flexible, approachable, responsive, intuitive and imaginative grows in prominence as an element of the 'customer value proposition' that may create a competitive advantage for a university. For the tutor to be aware of the whole spectrum of expectations of international students and their relative importance is a major step towards achieving student satisfaction. From the student's point of view, good quality education is strongly associated 
with the fulfilment of expectations that brought them to a foreign university in the first place (Aldridge and Rowley, 1998). Reported research findings point towards some positions that may help academics to raise their awareness of international market demand for their particular skills and routines. One of them is a need for closer monitoring of student perceptions that can be achieved through professional discourse with colleagues and the students regarding the values of university experience as seen by students. In this way tutors and students could move closer together in their expectations, without either group abandoning its own unique identities and beliefs (Durkin, 2008). Overall, this study is supportive of the view that higher education institutions should pursue a more inclusive approach to internationalisation, in which 'universities become internationally-minded communities, not simply institutions with increasingly large numbers of international students' (Robson and Turner, 2007).

The study contributes to better understanding of the perceptions of foreign students but because of its obvious limitations, further work is needed. An investigation of groups of students other than covered in this report is necessary to achieve a comprehensive view on the issue of customer value in higher education. Additional empirical research involving a greater number of business schools is also needed to confirm the findings of this study. Future research may consider a longitudinal design that would allow the researcher to capture changes in notions of career success as the individual progresses through the course of study. In order to identify potential shifts in the perceptions of the value of international business education, it would be desirable to link such analysis to the change of business conditions globally and in different countries.

\section{References}

Aldridge, S. and Rowley, J. (1998) Measuring Customer Satisfaction in Higher Education. Quality Assurance in Education, 6 (4), pp. 197-204.

Angelidis, J. and Ibrahim, N. (2004) An Exploratory Study of the Impact of Degree of Religiousness upon an Individual's Corporate Social Responsiveness Orientation. Fournal of Business Ethics, 51 (2), pp. 119-128.

Appleton-Knapp, S. L. and Krentler, K. A. (2006) Measuring Student Expectations and their Effects on Satisfaction: the Importance of Managing Student Expectation. Fournal of Marketing Education, 28 (3), pp. 254-264.

Armstrong, M. J. (2003) Students as Clients: a Professional Services Model for Business Education. Academy of Management Learning and Education, 2 (4), pp. 371374.

Baruch, Y. and Peiperl, M. (2000) The Impact of an MBA on Graduate Careers. Human Resource Management fournal, 10 (2), pp. 69-90. 
Baruch, Y., Bell, M. P. and Gray, D. (2005) Generalist and Specialist Graduate Business Degrees: Tangible and Intangible Value. Fournal of Vocational Behavior, 67 (1), pp. $51-68$.

Brennan, L. and Bennington, L. (2000) Concepts in Conflict: Students and Customers-an Australian Perspective. Fournal of Marketing for Higher Education, 9 (2), pp. 19-40.

Carmichael, T. and Sutherland, M. (2005) A Holistic Framework for the Perceived Return on Investment in an MBA. South African fournal of Business Management, 36 (2), pp. $57-70$.

Caruana, V. and Spurling, N. (2006) The Internationalisation of UK Higher Education: a Review of Selected Material. Higher Education Academy Report. http://www. heacademy.ac.uk/resources/detail/the_internationalisation_of_uk_he, last accessed 6 February 2011.

Connolly, M. (2003) The End of the MBA as We Know It. Academy of Management Learning and Education, 2 (4), pp. 365-367.

Currie, J. and Newson, J. (eds.) (1998) Universities and Globalization: Critical Perspectives. London: Sage Publications.

Devos, A. (2003) Academic Standards, Internationalisation, and the Discursive Construction of 'The International Student'. Higher Education Research and Development, 22 (2), pp. $155-166$.

Durkin, K. (2008) The Adaptation of East Asian Masters Students to Western Norms of Critical Thinking and Argumentation in the UK. Intercultural Education, 19 (1), pp. $15-27$.

Easterby-Smith, M., Thorpe, R. and Lowe, A. (2002) Management Research: An Introduction. London: Sage.

Finney, T. G. and Finney, R. Z. (2010) Are Students Their Universities' Customers? An Exploratory Study. Education + Training, 52 (4), pp. 276-291.

Gattiker, U. E. and Larwood, L. (1986) Subjective Career Success: a Study of Managers and Career Personnel. Fournal of Business and Psychology, 1 (2), pp. 78-94.

Gibson, A. (2010) Measuring Business Student Satisfaction: a Review and Summary of the Major Predictors. Fournal of Higher Education Policy and Management, 32 (3), pp. 251-259.

Hay, A. and Hodgkinson, M. (2006) Exploring MBA Career Success. Career Development International, 11 (2), pp. 108-124.

Healey, N. (2008) Is Higher Education Really 'Internationalising'. Higher Education, 55 (3), pp. 333-355.

Hemsley-Brown, J. V. and Oplatka, I. (2006) Universities in a Competitive Global Marketplace: a Systematic Review of the Literature on Higher Education Marketing. International Fournal of Public Sector Management, 19 (4), pp. 316-338.

Isserstedt, W. and Schnitzer, K. (2005) Internationalization of Higher Education: Foreign Students in Germany, German Students Abroad. Berlin: Federal Ministry of Education and Research.

Johnson, P. and Duberley, J. (2000) Understanding Management Research: an Introduction to Epistemology. London: Sage.

Jongbloed, B. (2003) Marketisation in Higher Education, Clark's Triangle and the Essential Ingredients of Markets. Higher Education Quarterly, 57 (2), pp. 110-135.

Kamvounias, P. and Varnham, S. (2006) Getting What They Paid For: Consumer Rights of Students in Higher Education. Griffith Law Review, 15 (2), pp. 306-332.

Lanning, M. J. (1998) Delivering Profitable Value. Oxford: Capstone Publishing Ltd.

Mai, L.-W. (2005) A Comparative Study between UK and US: the Student Satisfaction in Higher Education and Its Influential Factors. Fournal of Marketing Management, 21 (7), pp. 859-878.

Marginson, S. (2006) Dynamics of National and Global Competition in Higher Education. Fournal of Higher Education, 52 (1), pp. 1-39. 
Middlehurst, R. and Woodfield, S. (2007) Responding to the Internationalisation Agenda: Implications for Institutional Strategy. Higher Education Academy Research Project Report 05/06, York: http://www.heacademy.ac.uk/research/MiddleHurstWoodfield07.pdf, last accessed 24 May 2011.

Mihail, D. M. and Elefterie, K. A. (2006) Perceived Effects of an MBA Degree on Employability and Career Advancement. Career Development International, 11 (4), pp. 352-361.

Mintzberg, H. (2004) Managers, Not MBAs: Career International Development A Hard Look at the Soft Practice of Managing and Management Development. San Francisco, CA: Berrett-Koehler.

Molesworth, M., Nixon, L. and Scullion, R. (2009) Having, Being in Higher Education: the Marketisation of the University and the Transformation of the Student into Consumer. Teaching in Higher Education, 14 (3), pp. 277-287.

Murray, S. and Robinson, H. (2001) Graduates into Sales-Employer, Student and University Perspectives. Education and Training, 43 (3), pp. 139-145.

Newman, S. and Jahdi, K. (2009) Marketisation of Education: Marketing, Rhetoric and Reality. Fournal of Further and Higher Education, 33 (1), pp. 1-11.

Olssen, M. and Peters, M. A. (2005) Neoliberalism, Higher Education and the Knowledge Economy: from the Free Market to Knowledge Capitalism. Fournal of Education Policy, 20 (3), pp. 313-345.

Pfeffer, J. and Fong, C. T. (2003) Assessing Business Schools: Reply to Connolly. Academy of Management Learning and Education, 2 (4), pp. 368-370.

Porter, M. E. (2007) Doing Well at Doing Good: Do You Have a Strategy? Presentation at Willow Creek Association Leadership Summit South Barrington, Illinois, http://www. isc.hbs.edu/pdf/20070810_MEP_WillowCreekAssociation.pdf, last accessed 7 January 2011.

Robson, S. and Turner, Y. (2007) Teaching is a Co-Learning Experience: Academics Reflecting on Learning and Teaching in an 'Internationalized' Faculty. Teaching in Higher Education, 12 (1), pp. 41-54.

Sappey, J. and Bamber, G. J. (2007) Flexible Delivery in Business Schools: a Winning Strategy or Pandora's Box? Proceedings of the British Academy of Management 2007 Conference, 11-13 September. Warwick, UK. http://www98.griffith.edu.au/ dspace/bitstream/10072/18583/1/46961_Bamber.pdf, last accessed 7 November 2010.

Schein, E. H. and Van Maanen, J. (1977) Career Development. In J. R. Hackman and J. L. Suttle (eds.), Improving Life at Work: Behavioral Science Approaches to Organizational Change. Santa Monica, CA: Goodyear, pp. 30-95.

Schoenfeld, G. (2007) Does Emphasis of Return on Investment Affect the Educational Mission for MBA Programs? GMAC ® Research Reports RR-07-09, May 9, 2007. Graduate Management Admission Council, USA.

Systèm d'Observation Permanente sur la Migrations (SOPEMI) (2010) International Migration Outlook 2010. Paris: OECD.

Stier, J. (2003) Internationalisation, Ethnic Diversity and Acquisition of Intercultural Competencies. Intercultural Education, 14, pp. 77-91.

Teichler, U. (2004) The Changing Debate on Internationalization of Higher Education. Higher Education, 48 (1), pp. 5-26.

Tracy, J. and Waldfogel, J. (1997) The Best Business Schools: a Market-Based Approach. Fournal of Business, 701, pp. 1-31.

UK Higher Education International Unit (2010) International Higher Education in Facts and Figures. London: Higher Education International Unit, Universities UK.

Universities and Colleges Admissions Service (UCAS) (2009) Annual Report 2007-08. Cheltenham: UCAS.

Useem, M. and Karabel, J. (1986) Pathways to Top Corporate Management. American Sociological Review, 51 (2), pp. 184-200. 
Weick, K. and Berlinger, L. (1989) Career Improvisation in Self Designing Organisations. In M. B. Arthur, D. T. Hall and B. S. Lawrence (eds.), The Handbook of Career Theory. Cambridge: Cambridge University Press, pp. 313-328.

Wilson, D. A. (2007) Tomorrow, Tomorrow and Tomorrow: the 'Silent' Pillar. fournal of Management Development, 26 (1), pp. 84-86.

Woodruff, R. B. and Gardial, S. F. (1996) Know Your Customer. New Approaches to Understanding Customer Value and Satisfaction. Cambridge, MA: Blackwell Business. 